\title{
Influence of Light Spectra from LEDs and Scion $\times$ Rootstock Genotype Combinations on the Quality of Grafted Watermelon Seedlings
}

\author{
Filippos Bantis ${ }^{1, *(\mathbb{D})}$, Christodoulos Dangitsis ${ }^{2}$ and Athanasios Koukounaras ${ }^{1}$ (D) \\ 1 Department of Horticulture, Aristotle University, 54124 Thessaloniki, Greece; thankou@agro.auth.gr \\ 2 Agris S.A., Kleidi, 59300 Imathia, Greece; cdaggitsis@agris.gr \\ * Correspondence: fbantis@agro.auth.gr; Tel.: +30-2310-994123
}

check for

updates

Citation: Bantis, F.; Dangitsis, C.; Koukounaras, A. Influence of Light Spectra from LEDs and Scion $\times$

Rootstock Genotype Combinations on the Quality of Grafted Watermelon Seedlings. Plants 2021, 10, 353. https://doi.org/10.3390/plants 10020353

Academic Editor:

Sabine Demotes-Mainard

Received: 11 December 2020

Accepted: 10 February 2021

Published: 12 February 2021

Publisher's Note: MDPI stays neutral with regard to jurisdictional claims in published maps and institutional affiliations.

Copyright: (c) 2021 by the authors. Licensee MDPI, Basel, Switzerland. This article is an open access article distributed under the terms and conditions of the Creative Commons Attribution (CC BY) license (https:/ / creativecommons.org/licenses/by/ $4.0 /)$.

\begin{abstract}
Grafting is the main means of propagation for watermelon crops. The aim of the present study was to evaluate whether light quality during graft healing variably affects different scion $\times$ rootstock genotype combinations. Two watermelon hybrid scions (Sunny Florida F1 and Celine F1) and two interspecific squash rootstocks (Radik and TZ-148) were used, and four scion $\times$ rootstock genotype combinations derived. After grafting, we tested seven light-emitting diodes (LEDs), which provided narrow-band red (R) and blue (B); R-B with 36\% (36B), 24\% (24B), and 12\% (12B) blue; $12 \mathrm{~B}$ with additional far-red $(12 \mathrm{~B}+\mathrm{FR})$; and white $(\mathrm{W})$, in a healing chamber. In three genotype combinations, shoot length, leaf area, and shoot biomass were mainly enhanced under red-blue LEDs, while stem diameter was greater under R. In contrast, dry weight of roots, Dickson's quality index, and ratio of shoot dry weight/length were variably affected in each genotype combination. From the results, it is concluded that light treatments differentially affected each genotype combination, but some parameters involving biomass production show genotypic dependency.
\end{abstract}

Keywords: Citrullus lanatus; Cucurbita maxima $\times$ Cucurbita moschata; genotypic dependency; graft healing; light-emitting diodes

\section{Introduction}

Watermelon is valuable crop with 1.38 billion euros export value in 2019 throughout the world, with Europe having the highest export share of 54\% [1]. It is mainly cultivated in eastern Asia and the Mediterranean, but crops tend to face harsh environmental conditions (e.g., extreme temperature) due to off-season cultivation [2]. Moreover, land quality deteriorates over time because of successive land use, while pest and disease incidents are more frequent. Nowadays, vegetable grafting is commercially employed since it provides a plethora of important benefits. Specifically, grafting increases resistance to abiotic (i.e., extreme temperature, salinity, etc.), [3] and biotic (i.e., nematodes and soil-borne pathogens) factors [4], as well as enhances plant vigor [5] among other advantages. Among vegetable crops, grafting is a well-established propagation technique for Cucurbitaceae (i.e., watermelon, cucumber, etc.) and Solanaceae (i.e., tomato, pepper, etc.) species [6]. Watermelon in particular is known to achieve high compatibility when combined with cucurbit hybrids such as interspecific squash (Cucurbita moschata $\times$ Cucurbita maxima).

Production of grafted watermelon seedlings mainly takes place in modern nurseries in order to achieve high quality and lower cost. The whole procedure involves a critical period of healing in which environmental conditions such as relative humidity, temperature, and light must be controlled in a sensitive manner. Technological advancements offer the opportunity to fully control the abovementioned conditions in a growth chamber instead of greenhouse benches. Light in particular has an important role as an energy source as well as a signal perceived by pigments and protein photoreceptors [7]. Solely artificial lighting can be employed with light-emitting diodes (LEDs), which offer several advantages compared 
to traditional light sources (e.g., fluorescent lamps). Specifically, LEDs are beneficial for indoor production mainly due to their optional light quality and intensity, low energy consumption, minimum heat output, etc. [8].

Until today, only a few published research articles $[9,10]$ are related to the effects of light spectra on grafted watermelon seedlings. In addition, to our knowledge, there is no information available about the possible scion and rootstock genotype dependency after illumination with different light spectra in any graft-propagated vegetable species (i.e., watermelon, cucumber, tomato, pepper, etc.). According to the above, our aim was to evaluate whether light quality during healing variably affects different scion $\times$ rootstock genotype combinations for the production of grafted watermelon seedlings. In addition, we studied the effect of light composition on important qualitative characteristics with a view to enhancing the overall quality of the specific grafted watermelon seedling genotype combinations. Watermelon was selected due to its high economic and cultural value for the Greek and European markets. In general, the influence of light during the healing of grafted vegetable seedlings is a rather new and understudied field.

\section{Materials and Methods}

\subsection{Plant Material and Growth of Seedlings to Be Grafted}

The experiment was executed in the facilities of a commercial nursery (Agris S.A., Kleidi, Imathia, Greece), and all measurements were conducted at the Laboratory of Vegetable Crops of the Aristotle University of Thessaloniki, Greece.

Two watermelon (Citrullus lanatus L.) hybrids were used as scion materials, "Celine F1" and "Sunny Florida F1", while two interspecific squash hybrids were used as rootstock materials, "TZ-148" and "Radik". Seed material was provided by HM.Clause SA, PortesLes-Valence, France. Four genotype combinations derived from the abovementioned scion and rootstock hybrids: Celine F1 $\times$ TZ-148 $(\mathrm{Cel} \times \mathrm{TZ})$, Sunny Florida F1 $\times$ TZ-148 (Flor $\times$ TZ), Celine F1 $\times$ Radik $(\mathrm{Cel} \times$ Rad), and Sunny Florida F1 $\times$ Radik (Flor $\times$ Rad). In order to produce seedlings to be grafted, seeds from rootstock and scion hybrids were sowed in 128-cell and 171-cell plug trays (G.K. Rizakos S.A., Lamia, Greece), respectively. The substrate consisted of a 5:1:2 mixture of peat, perlite, and vermiculite. According to commercial practices, rootstock seeds were sown one day later in order for the scion and rootstock seedlings to develop proper stem diameter before grafting.

Afterward, sowed trays remained at $95-98 \%$ relative humidity and $25{ }^{\circ} \mathrm{C}$ temperature for 2 (rootstocks) or 3 days (scions), until germination. Upon germination, the trays were placed for 10 days in a Venlo-type greenhouse until grafting. Specifically, the scion hybrids were grown under $21.5^{\circ} \mathrm{C}$ minimum temperature and $18 \mathrm{~h}$ supplemental artificial lighting $\left(100 \pm 10 \mu \mathrm{mol} \mathrm{m}^{-2} \mathrm{~s}^{-1}\right)$ provided by high-pressure sodium lamps (MASTER GreenPower E40, Philips Lighting, Eindhoven, The Netherlands), while the rootstock hybrids were grown at $20^{\circ} \mathrm{C}$ minimum temperature, but no supplemental artificial lighting was required (according to unpublished data of our group).

\subsection{Grafting, Healing, and Light Conditions in the Healing Chamber}

Splice grafting was executed at the stage of one true leaf for both segments (i.e., scion and rootstock). At the same time, the entire root system was also removed from the rootstocks, which is common for increasing grafting efficiency of cucurbits [11]. Immediately, the freshly grafted seedlings were planted in 72-cell plug trays (peat, perlite, and vermiculite at 3:1:1 composition). For every light treatment and scion $\times$ rootstock genotype combination, one tray (72 grafted seedlings) was planted, and all procedures were assisted by professionals in order to limit errors.

Upon grafting, seedlings were placed in a healing chamber with precisely set conditions for 6 days. Specifically, the temperature was $25^{\circ} \mathrm{C}$, relative humidity initially was $98 \%$ and gradually dropped to $89 \%$, and air was recirculating. Conditions were controlled by a climate control system (Priva SA, De Lier, The Netherlands). 
Sole artificial lighting was provided by seven LEDs whose light distributions, yield photon fluxes (YPF), and phytochrome photostationary states (PPS) are presented in Table 1 (HD 30.1 spectroradiometer, DeltaOhm Srl, Padova, Italy). YPF and PPS values were calculated according to Sager et al. [12]. Briefly, LEDs emitted narrow-band red (R; peak wavelength at $661 \mathrm{~nm}$ ); narrow-band blue (B; peak wavelength at $450 \mathrm{~nm}$ ); three RB combinations, namely $12 \mathrm{~B}, 24 \mathrm{~B}$, and $36 \mathrm{~B}$ emitting 12,24 , and $36 \%$ blue, respectively; $12 \mathrm{~B}$ with supplemental far-red (12B+FR) light; and a white spectra (W) emitting $11 \%$ blue. W was selected due to the relatively high color rendering index (CRI $>50$ units) which is desirable in the workplace. The photoperiod was $18 \mathrm{~h}$, while photosynthetic photon flux density at plant top was $85 \pm 5 \mu \mathrm{mol} \mathrm{m}{ }^{-2} \mathrm{~s}^{-1}$. The LEDs were mounted on shelves (L: 2.00 $\mathrm{m} \times \mathrm{W}: 1.66 \mathrm{~m} \times \mathrm{H}: 0.76 \mathrm{~m}$ ) at a distance of $30 \mathrm{~cm}$ between LED and plant top.

Table 1. Spectral distribution, yield photon flux (YPF), and phytochrome photostationary state (PPS) for the light treatments tested. Values are percentages of total photons reaching the seedling canopy.

\begin{tabular}{|c|c|c|c|c|c|c|c|}
\hline \multirow{2}{*}{ Waveband } & \multicolumn{7}{|c|}{ Light Treatment } \\
\hline & $\mathbf{R}$ & B & $36 B$ & $24 B$ & 12B & 12B+FR & W \\
\hline UV \%; 380-399 nm & 0 & 0 & 0 & 0 & 0 & 0 & 0 \\
\hline Blue \%; 400-499 nm & 0 & 100 & 36 & 24 & 12 & 12 & 11 \\
\hline Green \%; 500-599 nm & 0 & 0 & 0 & 0 & 0 & 0 & 18 \\
\hline Red \%; 600-699 nm & 100 & 0 & 64 & 76 & 88 & 83 & 70 \\
\hline Far-red \%; 700-780 nm & 0 & 0 & 0 & 0 & 0 & 5 & 1 \\
\hline $\mathrm{YPF}\left(\mu \mathrm{mol} \mathrm{m} \mathrm{m}^{-2} \mathrm{~s}^{-1}\right)$ & 79.1 & 63.8 & 73.5 & 75.4 & 77.2 & 73.9 & 75.1 \\
\hline PPS & 0.89 & 0.51 & 0.88 & 0.89 & 0.89 & 0.88 & 0.89 \\
\hline
\end{tabular}

\subsection{Sampling and Measurements}

Upon exiting the healing chamber, 10 randomized grafted seedlings per genotype combination and light treatment were sampled, while quality parameter evaluations followed. According to a study of our group [13], the evaluated parameters are valuable for quality assortment of grafted watermelon seedlings. In particular, stem diameter and shoot length (i.e., length between the apical bud and the root collar) were measured with a Vernier caliper, while leaf area was determined with a LI-3000C area meter (LI-COR biosciences, Lincoln, NE, USA). Colorimetry was conducted with a CR-400 Chroma Meter (Konica Minolta Inc., Tokyo, Japan), and relative chlorophyll content was determined using a CCM-200 plus chlorophyll meter (Opti-Sciences, Hudson, NH, USA). In addition, dry weight (after 3 days in an oven at $72{ }^{\circ} \mathrm{C}$ ) of shoot and root was determined, while Dickson's quality index (DQI; a seedling quality indicator), root/shoot (R/S) ratio, and shoot dry weight/length $(\mathrm{DW} / \mathrm{L})$ ratio were also calculated from the obtained data. DQI was calculated according to Equation (1) [14]:

$$
D Q I=\frac{\text { Seedling total dry weight }(g)}{\frac{\text { Shoot length }(\mathrm{mm})}{\text { Stem diameter }(\mathrm{mm})}+\frac{\text { Shoot dry weight }(\mathrm{g})}{\text { Root dry weight }(\mathrm{g})}}
$$

\subsection{Statistical Analysis}

The experiment was conducted twice, with similar conclusions reached in each replication. Statistical analysis was performed using IBM SPSS software (SPSS 23.0, IBM Corp., Armonk, NY, USA). Data were compared by one-way and two-way analysis of variance (ANOVA) at significance level $p=0.05$, while mean comparisons were conducted using Tukey test at $\mathrm{a}=0.05$.

\section{Results and Discussion}

In the present study, we report that results from some parameters are consistent in most scion $\times$ rootstock genotype combinations, while results from a few parameters are attributed to genotypic dependency. According to two-way ANOVA, almost all tested 
parameters (11 out of 13) were significantly affected by the different light treatments (Supplementary Table S1). Morphological parameters are known to be induced by combinations of red and blue light [15]. However, distinct responses are induced by green and far-red lights, which also affect photomorphogenesis and photosynthesis $[16,17]$. On the contrary, only four parameters related to shoot and root dry biomass were significantly affected by scion $\times$ rootstock genotype combination (Supplementary Table S1), while the interaction between the two factors (light and scion $\times$ rootstock genotype combination) was significantly different for 9 out of 13 tested parameters (Supplementary Table S1). Moreover, it is obvious that light had a greater impact compared to scion $\times$ rootstock genotype combination and their interaction in several of the tested parameters.

Colorimetry showed significant differences in three genotype combinations, except for Cel $\times$ TZ. Specifically, in Flor $\times$ TZ narrow-band B developed a lighter color (greater lightness values) compared to $\mathrm{R}, 36 \mathrm{~B}, 24 \mathrm{~B}$, and 12B; more intense color (greater chroma values) compared to $36 \mathrm{~B}, 24 \mathrm{~B}$, and $12 \mathrm{~B}$; and significantly different hue angle and $\mathrm{a}^{*} / \mathrm{b}^{*}$ values compared to $36 \mathrm{~B}, 24 \mathrm{~B}$, and 12B (supplementary Table S2). Moreover, in Cel $\times \mathrm{Rad}$ narrow-band B developed lighter color compared to 36B, 24B, 12B, 12B+FR, and W, as well as more intense color and significantly different hue angle and $\mathrm{a}^{*} / \mathrm{b}^{*}$ values compared to the rest of the treatments (Supplementary Table S2). In Flor $\times$ Rad narrow-band B developed more intense color compared to $\mathrm{R}, 12 \mathrm{~B}+\mathrm{FR}$, and $\mathrm{W}$, and significantly different hue angle and $\mathrm{a}^{*} / \mathrm{b}^{*}$ values compared to $\mathrm{R}, 36 \mathrm{~B}$, and $12 \mathrm{~B}+\mathrm{FR}$ (Supplementary Table S2). According to Table S1, all colorimetric parameters tested were dependent on light but not genotype combination, while lightness and chroma were also dependent on light $x$ genotype combination. Literature about the effect of light quality on leaf coloration of seedlings is rather scarce, and only a few studies address it. For example, Craver and Lopez [18] suggested that LEDs with specific light qualities can be used for a few days to manipulate leaf coloration and promote the marketability of lettuce.

Leaf color parameters are strongly correlated to relative chlorophyll content [19]. However, no significant correlation was observed in our case (data not shown). Chlorophylls are basic structural and redox components of the light-harvesting complex of photosystems I and II; thus, their accumulation and allocation are indicative of the plant physiological status [20]. In Cel $\times \mathrm{Rad}$, relative chlorophyll content was greater under 24B compared to the rest of the light treatments, except for 12B (Table 2). No significant differences were found in the other three genotype combinations (Table 2). Narrow-band blue or red light has been found to decrease chlorophyll content in rose [21] and wheatgrass [22]. Blue light in particular induces chloroplast allocation to the cell surface in order to increase photosynthetic efficiency [23]. Moreover, red and blue light combinations have been reported to increase chlorophyll content in cucumber, which subsequently leads to enhanced photosynthetic activity [24]. Since relative chlorophyll content is not dependent on genotype combinations (Table S1), the absence of significant differences in three out of four genotype combinations can be attributed to the light $\times$ genotype combination, as well as to the limited time of healing and exposure to light of only 6 days.

Shoot length did not show significant differences among the light treatments in Flor $x$ $\mathrm{Rad}$ (Table 2). However, in $\mathrm{Cel} \times \mathrm{TZ}$, the parameter was enhanced under 36B compared to $\mathrm{R}, 12 \mathrm{~B}, 12 \mathrm{~B}+\mathrm{FR}$, and $\mathrm{W}$; in Flor $\times \mathrm{TZ}$, it was greater under 24B compared to all treatments except for 36B; while in $\mathrm{Cel} \times \mathrm{Rad}$, it was greater under $12 \mathrm{~B}+\mathrm{FR}$ compared to $\mathrm{R}, 24 \mathrm{~B}$, and $\mathrm{W}$ (Table 2). Shoot elongation is a shade-avoidance response triggered by different red and far-red photon flux densities. Red/far-red ratio activates a signaling cascade involving photoreceptors (i.e., phytochromes), genes (i.e., phytochrome interacting factors-PIFs), and plant growth regulators such as auxins [16]. Strikingly, no significant differences were observed in shoot length between $12 \mathrm{~B}$ and $12 \mathrm{~B}+\mathrm{FR}$ in any genotype combination, probably due to the short period of healing (six days). In general, the shoot length of each genotype combination seems to be variably affected by different spectra.

Regarding stem diameter development, $\mathrm{Cel} \times \mathrm{TZ}$, narrow-band $\mathrm{R}$ induced the development of greater values compared to B, while in Flor $\times \mathrm{TZ}$, narrow-band $\mathrm{R}$ promoted its 
development compared to the rest of the treatments except for 36B (Figure 1). Moreover, in $\mathrm{Cel} \times \mathrm{Rad}, 24 \mathrm{~B}$ led to greater values compared to 12B, while in Flor $\times$ Rad narrow-band $\mathrm{R}$ promoted stem diameter development compared to $\mathrm{B}, 12 \mathrm{~B}, 12 \mathrm{~B}+\mathrm{FR}$, and $\mathrm{W}$ (Figure 1). Stem diameter of tomato and pepper seedlings was greater under narrow-band $\mathrm{R}$ compared to red-blue and narrow-band B treatments [25]. In a more recent study, tomato seedlings developed greater stem diameter under $\mathrm{R}$ and red-blue LEDs compared to narrow-band B [26].
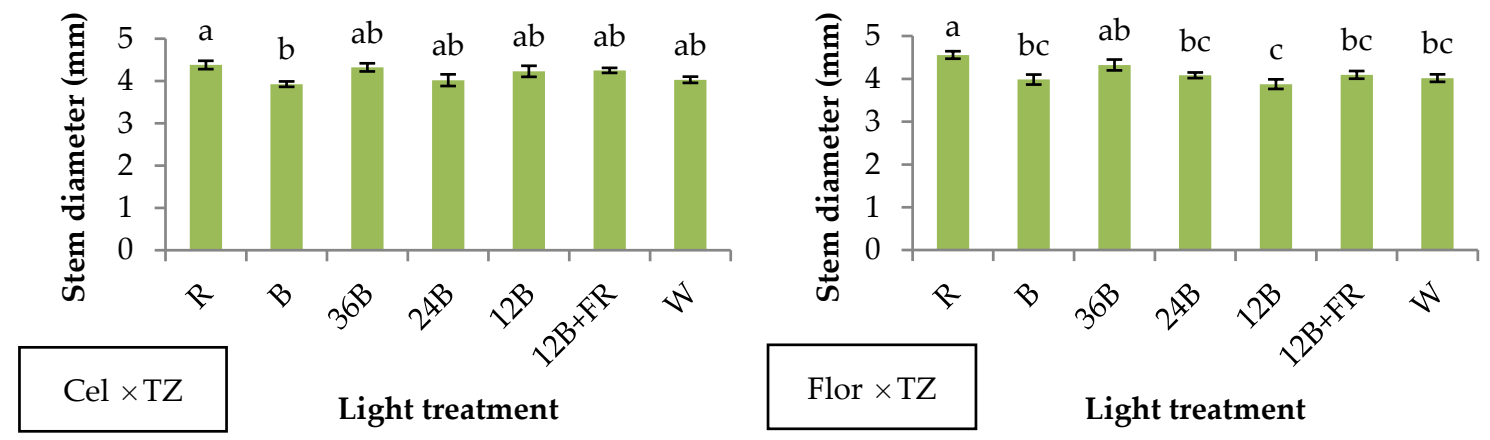

Flor $\times \mathrm{TZ} \quad$ Light treatment
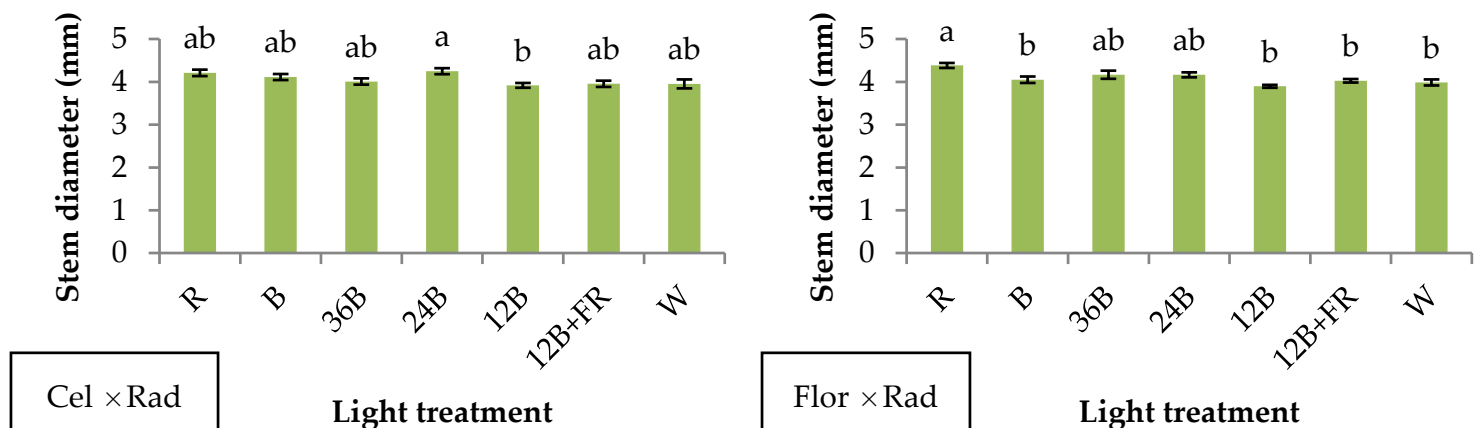

Figure 1. Stem diameter of grafted watermelon seedlings derived from four watermelon $\times$ interspecific squash genotype combinations, and after illumination by seven light treatments during healing. Bars $( \pm \mathrm{SE})$ followed by different letters are significantly different $(p \leq 0.05)$

Table 2. Shoot length, root/shoot (R/S) ratio, relative chlorophyll (chl) content, shoot dry weight/length (DW/L) ratio, and Dickson's quality index (DQI) of grafted watermelon seedlings derived from four watermelon $\times$ interspecific squash genotype combinations, and after illumination by seven light treatments during healing. Mean values ( \pm SE) within a scion $\times$ rootstock genotype combination followed by different letters are significantly different $(p \leq 0.05)$.

\begin{tabular}{|c|c|c|c|c|c|}
\hline Light Treatment & Shoot Length (mm) & R/S Ratio & Chl Content & $\mathrm{DW} / \mathrm{L} \times 1000$ & $\mathrm{DQI} \times 1000$ \\
\hline \multicolumn{6}{|c|}{ Celine F1 $\times$ TZ-148 } \\
\hline $\mathrm{R}$ & $31.23 \pm 1.68 \mathrm{~b}$ & $0.20 \pm 0.02 \mathrm{a}$ & $27.48 \pm 1.58 \mathrm{a}$ & $4.93 \pm 0.32 \mathrm{a}$ & $14.29 \pm 1.09 \mathrm{abc}$ \\
\hline B & $36.31 \pm 1.40 \mathrm{ab}$ & $0.18 \pm 0.02 \mathrm{a}$ & $28.55 \pm 1.79 a$ & $3.91 \pm 0.12 \mathrm{~cd}$ & $11.15 \pm 0.73 \mathrm{c}$ \\
\hline $36 B$ & $39.75 \pm 1.27 \mathrm{a}$ & $0.18 \pm 0.01 \mathrm{a}$ & $30.73 \pm 2.93 a$ & $3.73 \pm 0.21 \mathrm{~d}$ & $11.98 \pm 1.16 \mathrm{bc}$ \\
\hline $24 \mathrm{~B}$ & $36.41 \pm 0.78 \mathrm{ab}$ & $0.17 \pm 0.01 \mathrm{a}$ & $29.18 \pm 1.26 \mathrm{a}$ & $4.06 \pm 0.26 \mathrm{~cd}$ & $11.16 \pm 1.38 c$ \\
\hline 12B & $33.78 \pm 0.99 b$ & $0.19 \pm 0.01 \mathrm{a}$ & $32.39 \pm 1.99 \mathrm{a}$ & $4.82 \pm 0.24 \mathrm{ab}$ & $15.78 \pm 1.21 \mathrm{a}$ \\
\hline $12 \mathrm{~B}+\mathrm{FR}$ & $33.96 \pm 1.03 \mathrm{~b}$ & $0.23 \pm 0.02 \mathrm{a}$ & $28.08 \pm 2.41 \mathrm{a}$ & $4.58 \pm 0.29 \mathrm{abc}$ & $15.25 \pm 0.60 \mathrm{ab}$ \\
\hline W & $33.86 \pm 1.75 b$ & $0.21 \pm 0.03 \mathrm{a}$ & $28.08 \pm 1.66 \mathrm{a}$ & $4.58 \pm 0.21 \mathrm{abc}$ & $14.15 \pm 1.56 \mathrm{abc}$ \\
\hline \multicolumn{6}{|c|}{ Sunny Florida F1 × TZ-148 } \\
\hline $\mathrm{R}$ & $31.55 \pm 2.24 \mathrm{~b}$ & $0.26 \pm 0.01 \mathrm{a}$ & $28.95 \pm 1.66 \mathrm{a}$ & $5.07 \pm 0.42 \mathrm{a}$ & $18.28 \pm 1.50 \mathrm{a}$ \\
\hline B & $33.47 \pm 1.15 b$ & $0.21 \pm 0.02 \mathrm{ab}$ & $23.84 \pm 2.08 \mathrm{a}$ & $4.27 \pm 0.20 \mathrm{bc}$ & $13.44 \pm 0.91 \mathrm{~b}$ \\
\hline $36 \mathrm{~B}$ & $35.49 \pm 1.16 \mathrm{ab}$ & $0.19 \pm 0.02 \mathrm{ab}$ & $29.54 \pm 1.68 \mathrm{a}$ & $4.40 \pm 0.28 \mathrm{abc}$ & $13.28 \pm 1.81 \mathrm{~b}$ \\
\hline $24 \mathrm{~B}$ & $41.46 \pm 1.57 \mathrm{a}$ & $0.19 \pm 0.02 \mathrm{ab}$ & $30.43 \pm 1.74 \mathrm{a}$ & $3.97 \pm 0.20 c$ & $12.05 \pm 0.52 b$ \\
\hline $12 \mathrm{~B}$ & $31.44 \pm 1.01 \mathrm{~b}$ & $0.17 \pm 0.01 \mathrm{~b}$ & $28.71 \pm 1.82 \mathrm{a}$ & $4.21 \pm 0.25 \mathrm{bc}$ & $10.48 \pm 0.56 b$ \\
\hline $12 \mathrm{~B}+\mathrm{FR}$ & $33.01 \pm 1.41 \mathrm{~b}$ & $0.18 \pm 0.01 b$ & $26.78 \pm 1.48 \mathrm{a}$ & $4.76 \pm 0.21 \mathrm{ab}$ & $12.68 \pm 0.68 b$ \\
\hline W & $33.37 \pm 0.86 b$ & $0.18 \pm 0.02 b$ & $26.23 \pm 0.94 a$ & $4.26 \pm 0.12 b c$ & $11.78 \pm 0.95 b$ \\
\hline
\end{tabular}


Table 2. Cont.

\begin{tabular}{|c|c|c|c|c|c|}
\hline Light Treatment & Shoot Length (mm) & R/S Ratio & Chl Content & $\mathrm{DW} / \mathrm{L} \times 1000$ & $\mathrm{DQI} \times 1000$ \\
\hline \multicolumn{6}{|c|}{ Celine F1 × Radik } \\
\hline $\mathrm{R}$ & $32.05 \pm 1.35 \mathrm{~b}$ & $0.09 \pm 0.03 \mathrm{a}$ & $26.11 \pm 1.35 \mathrm{bc}$ & $4.18 \pm 0.14 b$ & $10.93 \pm 0.39 b c$ \\
\hline B & $36.58 \pm 1.98 \mathrm{ab}$ & $0.11 \pm 0.03 \mathrm{a}$ & $20.79 \pm 1.58 c$ & $3.78 \pm 0.25 b c$ & $11.99 \pm 0.66 \mathrm{abc}$ \\
\hline $36 \mathrm{~B}$ & $33.67 \pm 1.04 \mathrm{ab}$ & $0.13 \pm 0.04 \mathrm{a}$ & $25.48 \pm 1.67 \mathrm{bc}$ & $3.93 \pm 0.13 b c$ & $11.82 \pm 0.48 \mathrm{abc}$ \\
\hline $24 B$ & $31.08 \pm 1.20 \mathrm{~b}$ & $0.11 \pm 0.03 \mathrm{a}$ & $36.10 \pm 2.87 \mathrm{a}$ & $4.92 \pm 0.29 \mathrm{a}$ & $13.43 \pm 0.72 \mathrm{a}$ \\
\hline 12B & $34.65 \pm 1.19 \mathrm{ab}$ & $0.11 \pm 0.03 \mathrm{a}$ & $29.29 \pm 1.35 \mathrm{ab}$ & $4.25 \pm 0.13 b$ & $11.49 \pm 0.84 b c$ \\
\hline $12 \mathrm{~B}+\mathrm{FR}$ & $39.26 \pm 1.46 \mathrm{a}$ & $0.12 \pm 0.04 \mathrm{a}$ & $28.30 \pm 1.77 \mathrm{bc}$ & $3.47 \pm 0.19 c$ & $10.52 \pm 0.75 c$ \\
\hline W & $31.91 \pm 1.47 \mathrm{~b}$ & $0.12 \pm 0.04 \mathrm{a}$ & $26.69 \pm 1.27 \mathrm{bc}$ & $4.31 \pm 0.25 \mathrm{~b}$ & $12.72 \pm 0.59 \mathrm{ab}$ \\
\hline \multicolumn{6}{|c|}{ Sunny Florida F1 $\times$ Radik } \\
\hline $\mathrm{R}$ & $31.79 \pm 1.59 \mathrm{a}$ & $0.20 \pm 0.01 \mathrm{a}$ & $28.68 \pm 1.97 \mathrm{a}$ & $4.59 \pm 0.25 \mathrm{a}$ & $15.08 \pm 1.12 \mathrm{a}$ \\
\hline B & $35.02 \pm 1.05 \mathrm{a}$ & $0.19 \pm 0.02 \mathrm{a}$ & $23.61 \pm 1.06 \mathrm{a}$ & $3.99 \pm 0.24 b$ & $13.19 \pm 0.93 \mathrm{ab}$ \\
\hline $36 \mathrm{~B}$ & $34.57 \pm 0.91 \mathrm{a}$ & $0.19 \pm 0.02 a$ & $28.45 \pm 3.41 \mathrm{a}$ & $4.15 \pm 0.07 \mathrm{ab}$ & $12.88 \pm 1.00 \mathrm{ab}$ \\
\hline $24 B$ & $36.26 \pm 1.24 \mathrm{a}$ & $0.18 \pm 0.01 \mathrm{a}$ & $24.50 \pm 1.56 \mathrm{a}$ & $4.36 \pm 0.18 \mathrm{ab}$ & $13.22 \pm 0.54 \mathrm{ab}$ \\
\hline 12B & $33.04 \pm 0.66 \mathrm{a}$ & $0.17 \pm 0.01 \mathrm{a}$ & $25.95 \pm 1.33 \mathrm{a}$ & $4.23 \pm 0.12 \mathrm{ab}$ & $11.39 \pm 0.70 b$ \\
\hline $12 \mathrm{~B}+\mathrm{FR}$ & $36.12 \pm 0.84 \mathrm{a}$ & $0.18 \pm 0.01 \mathrm{a}$ & $30.35 \pm 1.65 \mathrm{a}$ & $4.03 \pm 0.15 b$ & $12.06 \pm 0.98 b$ \\
\hline W & $32.62 \pm 0.82 \mathrm{a}$ & $0.18 \pm 0.01 \mathrm{a}$ & $30.00 \pm 1.24 \mathrm{a}$ & $4.27 \pm 0.18 \mathrm{ab}$ & $12.80 \pm 0.88 \mathrm{ab}$ \\
\hline
\end{tabular}

Leaf area exhibited the lowest numerical (but not always significantly different) values under B in three genotype combinations, except for Cel $\times$ Rad (Figure 2). Specifically, in Cel $\times$ TZ, narrow-band B had lower values compared to R, 24B, 12B, and 12B+FR; in Flor $\times$ T, B had lower values compared to 36B, 24B, and 12B+FR; while in Flor $\times$ Rad, $\mathrm{B}$ had lower values compared to $\mathrm{R}$ and $24 \mathrm{~B}$ (Figure 2). The rest of the light treatments emitting various percentages of red light did not show significant differences among each other (Figure 2). Cope and Bugbee [27] found that radish and soybean showed a different response to blue light and that relative blue light was a better leaf area indicator compared to absolute blue light. In general, blue light is involved in the inhibition of cell expansion and division [28], thus leading to lower leaf area [29]. Specifically, blue light inhibits leaf expansion by imposing an imbalance in the expression of certain genes involved in the vertical and horizontal leaf development [30,31]. In three out of four genotypes tested (except for Cel $\times$ Rad), it is evident that the presence of red light at any level is sufficient for the adequate development of leaf area irrespective of the presence of other light bands.

Two genotype combinations involving Sunny Florida F1 scion (Flor $\times$ TZ and Flor $\times$ Rad) developed greater shoot dry weight under 24B compared to B, 12B, and W (Figure 3). The same treatment, 24B, also enhanced shoot dry weight of $\mathrm{Cel} \times \mathrm{Rad}$ compared to $\mathrm{R}, 36 \mathrm{~B}$, 12B+FR, and $\mathrm{W}$, while no significant differences were observed in $\mathrm{Cel} \times \mathrm{TZ}$ (Figure 3). The above-mentioned results indicate significant genotypic dependency among the scion $\times$ rootstock combinations, which is expressed under different light treatments (Supplementary Table S1). Quite similarly, sprouts and seedlings from seven rapeseed genotypes responded variably regarding their biomass accumulation when illuminated with high $(32 \%)$ blue or low $(15 \%)$ blue light from LEDs [32]. Moreover, dry mass production of two lemon balm genotypes was differentially affected by white, red, blue, and red-blue LEDs under normal and drought conditions [33]. 

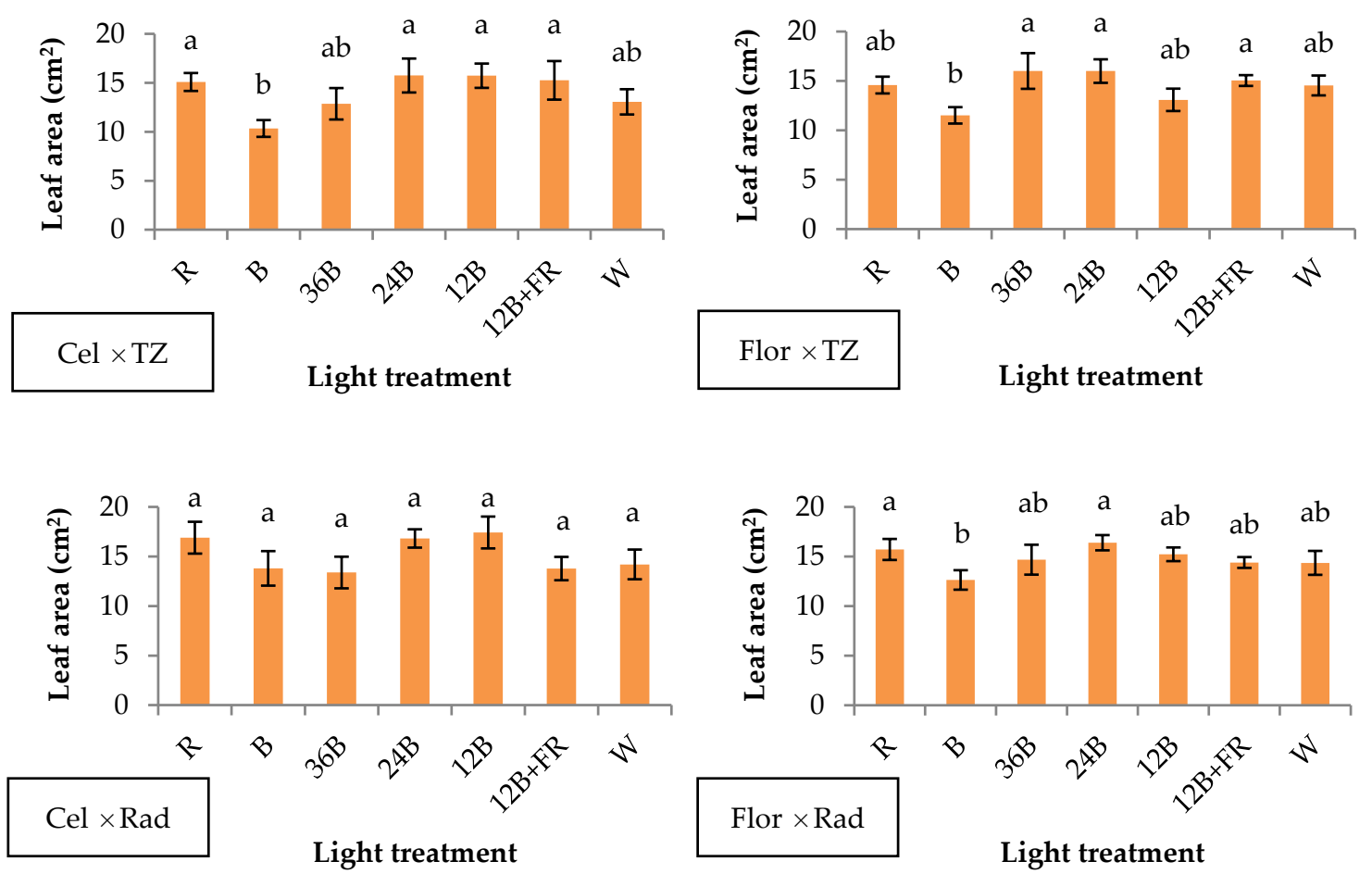

Figure 2. Leaf area of grafted watermelon seedlings derived from four watermelon $\times$ interspecific squash genotype combinations, and after illumination by seven light treatments during healing. Bars $( \pm S E)$ followed by different letters are significantly different $(p \leq 0.05)$.
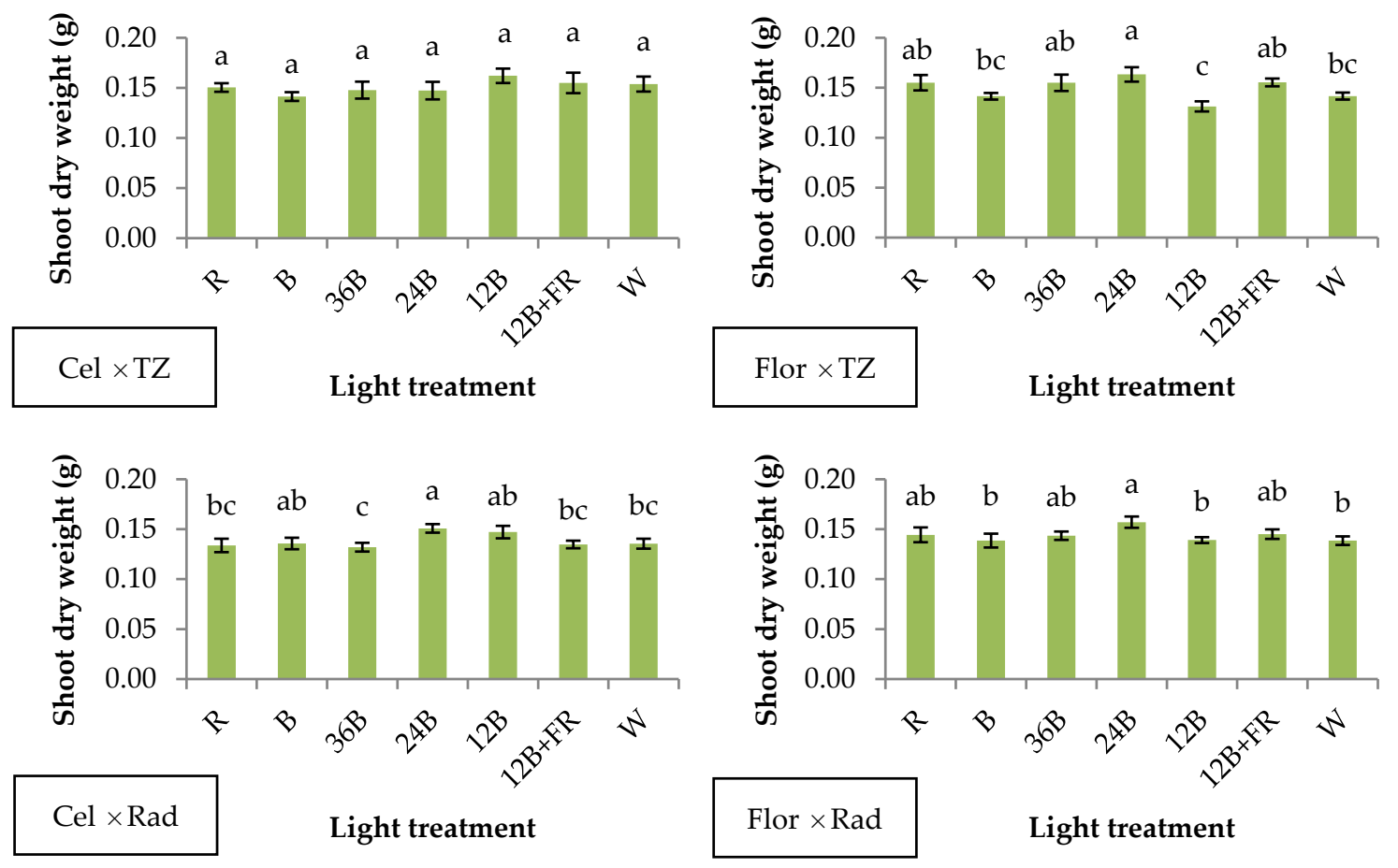

Figure 3. Shoot dry weight of grafted watermelon seedlings derived from four watermelon $\times$ interspecific squash genotype combinations, and after illumination by seven light treatments during healing. Bars $( \pm \mathrm{SE})$ followed by different letters are significantly different $(p \leq 0.05)$.

Chlorophylls are responsible for photon capture and electron delivery in the photosystems, leading to photosynthesis. Their main light absorption spectral regions coincide with the red and blue wavelengths; thus, photosynthesis is mainly driven by red and blue 
light [34]. Previous research of our group [10] that focused on Cel $\times$ TZ demonstrated that $12 \mathrm{~B}$ and $24 \mathrm{~B}$ treatments enhanced several quality features of grafted watermelon seedlings. In the present research, it is shown that $24 \mathrm{~B}$ is beneficial for the biomass production of three out of four genotype combinations compared to some of the light treatments tested, but 12B leads to inferior shoot biomass in genotype combinations, including Sunny Florida F1 (i.e., Flor $\times$ TZ and Flor $\times$ Rad), compared to some of the light treatments tested (Figure 3). This observation highlights the influence of scion genotype on the aboveground biomass accumulation under specific light wavelengths. In addition, in all genotype combinations, narrow-band ( $\mathrm{R}$ and $\mathrm{B}$ ) treatments induced the production of seedlings with similar biomass compared to red- and blue-containing treatments.

Root dry weight showed variable results in each genotype combination (Figure 4). Specifically, in Cel $\times \mathrm{TZ}$, the parameter was enhanced under 12B, 12B+FR, and W compared to $B$ and 24B (Figure 4). Narrow-band R promoted root dry weight in Flor $\times$ TZ compared to the rest of the light treatments (Figure 4). On the contrary, R light led to the lowest values in $\mathrm{Cel} \times \mathrm{Rad}$ compared to all blue-containing light treatments, while no significant differences were found in Flor $\times$ Rad (Figure 4). The results indicate genotype dependency since the four genotype combinations showed different responses to the light treatments (Supplementary Table S1). It is noteworthy that B and 24B in Cel $\times$ Rad produced $+30 \%$ root biomass compared to $\mathrm{R}$, indicating the importance of rootstock $\times$ scion genotype combination for proper root development. Poudel et al. [35] reported enhanced root parameters (rooting percentage and root length) of two grape cultivars grown under narrow-band red LEDs, while one cultivar did not show any significant differences, possibly due to genotype dependency. In addition, only two out of nine tomato genotypes reportedly showed enhanced root length under $88 \%$ red $/ 12 \%$ blue light spectra (similar to our $12 \mathrm{~B}$ light treatment) compared to narrow-band red light [36].
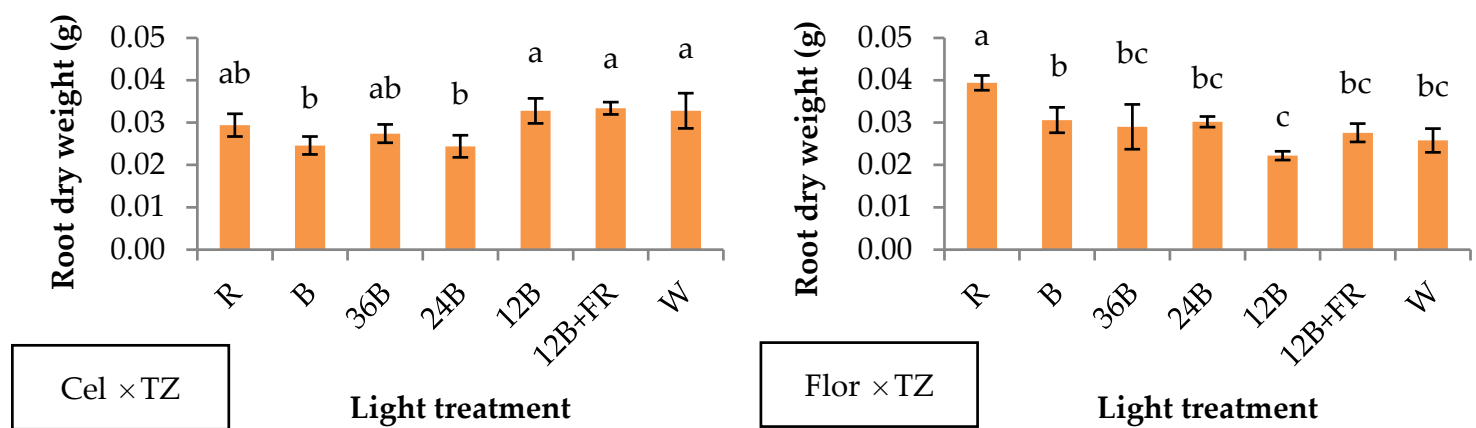

Flor $\times \mathrm{TZ} \quad$ Light treatment
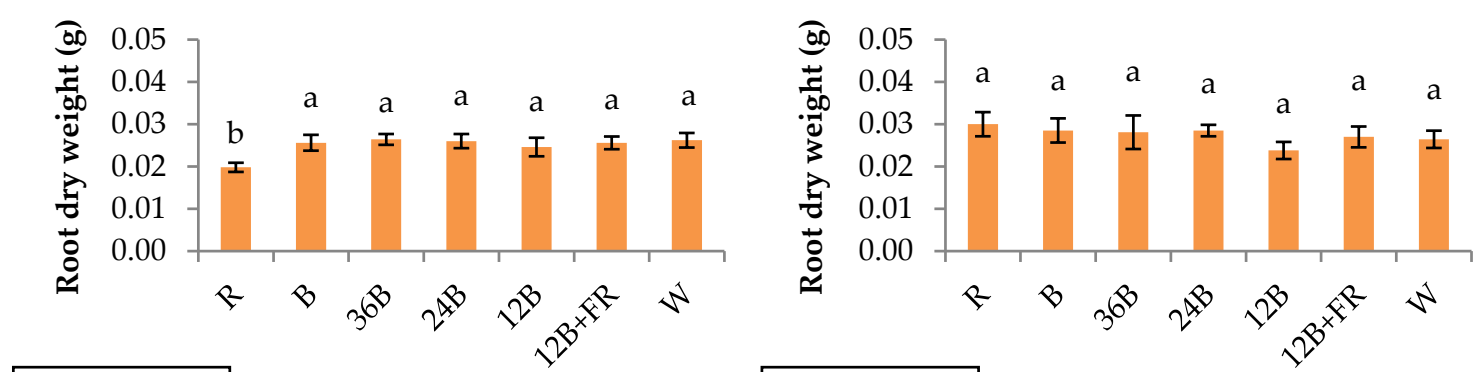

Cel $\times \operatorname{Rad}$

Light treatment

Flor $\times$ Rad

Light treatment

Figure 4. Root dry weight of grafted watermelon seedlings derived from four watermelon $\times$ interspecific squash genotype combinations, and after illumination by seven light treatments during healing. Bars $( \pm \mathrm{SE})$ followed by different letters are significantly different $(p \leq 0.05)$.

$\mathrm{R} / \mathrm{S}$ ratio is an indicator of biomass allocation (underground and aboveground) within a plant and potentially demonstrates the plant's ability to successfully establish in new ground after transplanting. This ratio is highly reliant on a possible genotype-dependent 
parameter, root dry weight, and a genotype- and light-dependent parameter, shoot dry weight. In our case, $\mathrm{R} / \mathrm{S}$ ratio was not significantly affected by the different light treatments in three genotype combinations (Table 2). However, in Flor $\times \mathrm{TZ}$, narrow-band R exhibited greater $R / S$ ratio values compared to $12 \mathrm{~B}, 12 \mathrm{~B}+\mathrm{FR}$, and $\mathrm{W}$ (Table 2 ). In this genotype combination, $\mathrm{R} / \mathrm{S}$ ratio followed the trend of root dry weight, with $\mathrm{R}$ showing the highest values, indicating that the former parameter was mainly influenced by the latter parameter. In general, genotype combinations showed similar responses of R/S ratio to light quality except for $\mathrm{Cel} \times$ Rad. Similar genotypic and light responses were also reported for seedlings of three artichoke cultivars [37].

Two seedling quality indicators, DW/L and DQI, were also calculated from the obtained data (Table 2). The two parameters are valuable indicators of the quality of grafted watermelon seedlings [13]. Specifically, in Cel $\times$ TZ, DW $/$ L exhibited greater values in R-treated seedlings compared to B, 36B, and 24B; in Flor $\times$ TZ, it showed greater values in $\mathrm{R}$ compared to $\mathrm{B}, 24 \mathrm{~B}, 12 \mathrm{~B}$, and $\mathrm{W}$; in $\mathrm{Cel} \times \mathrm{Rad}, \mathrm{DW} / \mathrm{L}$ exhibited greater values in $24 \mathrm{~B}$ compared to the rest of the treatments; while in Flor $\times$ Rad, it presented greater values in $R$ treated seedlings compared to B and 12B+FR (Table 2). Regarding DQI, in Cel $\times$ $\mathrm{TZ}$, greater values were obtained in $12 \mathrm{~B}$ compared to $\mathrm{B}, 24 \mathrm{~B}$, and $36 \mathrm{~B}$; in Flor $\times \mathrm{TZ}$, greater values were found in $\mathrm{R}$ compared to the rest of the treatments; in $\mathrm{Cel} \times \mathrm{Rad}$, greater values were determined in $24 \mathrm{~B}$ compared to $12 \mathrm{~B}+\mathrm{FR}, 12 \mathrm{~B}$, and $\mathrm{R}$; while in Flor $\times$ Rad, greater values were obtained in $\mathrm{R}$ compared to $12 \mathrm{~B}$ and $12 \mathrm{~B}+\mathrm{FR}$ (Table 2). These results highlight the importance of red and blue lights for plant development. In addition, it is reaffirmed that grafted seedling development under various light wavelengths is highly dependent on the scion $\times$ rootstock genotype.

\section{Conclusions}

Parameters involving biomass production (dry weight of shoot and root, DQI, and $\mathrm{DW} / \mathrm{L}$ ) clearly revealed genotypic dependencies, since the different scion $\times$ rootstock combinations variably responded to the light treatments. For morphological parameters such as stem diameter, shoot length, and leaf area, it is concluded that light treatment differentially affected each genotype combination. Moreover, it is proven that small interplays in the light spectra such as the ones demonstrated between $12 \mathrm{~B}$ and $12 \mathrm{~B}+\mathrm{FR}$, or between $12 \mathrm{~B}$ and $\mathrm{W}$, do not variably affect the status of grafted watermelon seedlings, possibly due to the short time of exposure (only six days) under each wavelength. Regardless of our results, a point that has to be made is that $\mathrm{W}$ is a positive treatment for practical applications due to the high color rendering index (over 50 units), thus providing a favorable working environment compared to the rest of the light treatments, and this feature should also be taken into consideration during light quality selection.

Supplementary Materials: The following are available online at https:/ / www.mdpi.com/2223-774 7/10/2/353/s1, Table S1: Analysis of variance for the effect of light treatment and watermelon $\times$ interspecific squash $(\mathrm{W} \times \mathrm{S})$ genotype combination on important qualitative characteristics of grafted watermelon seedlings. R/S: root-to-shoot dry weight ratio; Chl content: relative chlorophyll content; DW/L: shoot dry weight-to-length ratio; DQI: Dickson's quality index; $\mathrm{a}^{*}$ : red/green coordinate; $\mathrm{b}^{*}$ : yellow/blue coordinate, Table S2: Colorimetric parameters of grafted watermelon seedlings derived from four watermelon $x$ interspecific squash genotype combinations, and after illumination by seven light treatments during healing. $a^{*}$ : red/green coordinate; $b^{*}$ : yellow/blue coordinate. Mean values $( \pm \mathrm{SE})$ within a scion $\times$ rootstock genotype combination followed by different letters are significantly different $(p \leq 0.05)$.

Author Contributions: Conceptualization, methodology, and data analysis: F.B. and A.K.; experimental measurements: F.B. and C.D.; writing-original draft preparation: F.B.; writing-review and editing: F.B., C.D. and A.K.; supervision and project administration: A.K. All authors have read and agreed to the published version of the manuscript. 
Funding: This research has been co-financed by the European Union and Greek national funds through the Operational Program Competitiveness, Entrepreneurship, and Innovation, under the call RESEARCH- CREATE-INNOVATE (project code: T1EDK-00960, LEDWAR.gr).

Data Availability Statement: Not applicable.

Conflicts of Interest: The authors declare no conflict of interest. The founding sponsors had no role in the design of the study; in the collection, analyses, or interpretation of data; in the writing of the manuscript; or in the decision to publish the results.

\section{References}

1. Worldstopexports.com. Available online: http://www.worldstopexports.com/watermelon-exports-by-country/ (accessed on 10 November 2020).

2. Lee, S.G. Production of high quality vegetable seedling grafts. Acta Hortic 2007, 759, 169-174. [CrossRef]

3. Schwarz, D.; Rouphael, Y.; Colla, G.; Venema, J.H. Grafting as a tool to improve tolerance of vegetables to abiotic stresses: Thermal stress, water stress and organic pollutants. Sci. Hortic. 2010, 127, 162-171. [CrossRef]

4. Lee, J.-M.; Kubota, C.; Tsao, S.J.; Bie, Z.; Echevarria, P.H.; Morra, L.; Odag, M. Current status of vegetable grafting: Diffusion, grafting techniques, automation. Sci. Hortic. 2010, 127, 93-105. [CrossRef]

5. Savvas, D.; Colla, G.; Rouphael, Y.; Schwarz, D. Amelioration of heavy metal and nutrient stress in fruit vegetables by grafting. Sci. Hortic. 2010, 127, 156-161. [CrossRef]

6. Davis, A.R.; Perkins-Veazie, P.; Hassell, R.; Levi, A.; King, S.R.; Zhang, X. Grafting effects on vegetable quality. HortScience 2008, 43, 1670-1672. [CrossRef]

7. Whitelam, G.; Halliday, K. Light and Plant Development; Blackwell Publishing: Oxford, UK, 2007.

8. Bourget, C.M. An introduction to light-emitting diodes. HortScience 2008, 43, 1944-1946. [CrossRef]

9. Li, X.E.; Liu, F.Y.; Huang, Y.; Kong, Q.S.; Wan, Z.J.; Li, X.; Bie, Z.L. Growth and physiology of grafted watermelon seedlings as affected by different light sources. Acta Hortic 2015, 1086, 59-64. [CrossRef]

10. Bantis, F.; Koukounaras, A.; Siomos, A.S.; Fotelli, M.N.; Kintzonidis, D. Bichromatic red and blue LEDs during healing enhance the vegetative growth and quality of grafted watermelon seedlings. Sci. Hortic. 2020, 109000. [CrossRef]

11. Lee, J.M.; Oda, M. Grafting of herbaceous vegetable and ornamental crops. In Horticultural Review; Janick, J., Ed.; John Wiley \& Sons: New York, NY, USA, 2003; pp. 61-124.

12. Sager, J.C.; Smith, W.O.; Edwards, J.L.; Cyr, K.L. Photosynthetic Efficiency and Phytochrome Photoequilibria Determination Using Spectral Data. Trans ASAE 1988, 31, 1882-1889. [CrossRef]

13. Bantis, F.; Koukounaras, A.; Siomos, A.; Menexes, G.; Dangitsis, C.; Kintzonidis, D. Assessing quantitative criteria for characterization of quality categories for grafted watermelon seedlings. Horticulturae 2019, 5, 16. [CrossRef]

14. Dickson, A.; Leaf, A.L.; Hosner, J.F. Quality appraisal of white spruce and white pine seedling stock in nurseries. For. Chron. 1960, 36, 10-13. [CrossRef]

15. Mohr, H.; Kendrick, R.E.; Kronenberg, G.H.M. (Eds.) Photomorphogenesis in Plants, 2nd ed.; Kluwer Academic Publishers: Dordrecht, The Netherlands, 1994; pp. 353-373.

16. Casal, J.J. Photoreceptor signaling networks in plant responses to shade. Annu. Rev. Plant Biol. 2013, 64, 403-427. [CrossRef]

17. Smith, H.L.; Mcausland, L.; Murchie, E.H. Don't ignore the green light: Exploring diverse roles in plant processes. J. Exp. Bot. 2017, 68, 2099-2110. [CrossRef] [PubMed]

18. Craver, J.K.; Lopez, R.G. Control of Morphology by Manipulating Light Quality and Daily Light Integral Using LEDs. In LED Lighting for Urban Agriculture; Kozai, T., Fujiwara, K., Runkle, E., Eds.; Springer: Singapore, 2016; pp. $203-217$.

19. Madeira, A.C.; Ferreira, A.; De Varennes, A.; Vieira, M.I. SPAD meter versus tristimulus colorimeter to estimate chlorophyll content and leaf color in sweet pepper. Commun. Soil Sci. Plant Anal. 2003, 34, 2461-2470. [CrossRef]

20. Strasser, R.J.; Tsimilli-Michael, M.; Qiang, S.; Goltsev, V. Simultaneous in vivo recording of prompt and delayed fluorescence and 820-nm reflection changes during drying and after rehydration of the resurrection plant Haberlea rhodopensis. Biochim. Biophys. Acta 2010, 1797, 1313-1326. [CrossRef]

21. Abidi, F.; Girault, T.; Douillet, O.; Guillemain, G.; Sintes, G.; Laffaire, M.; Ahmed, H.B.; Smiti, S.; Huché-Thélier, L.; Leduc, N. Blue light effects on rose photosynthesis and photomorphogenesis. Plant Biol. 2013, 15, 67-74. [CrossRef] [PubMed]

22. Bartucca, M.L.; Guiducci, M.; Falcinelli, B.; Del Buono, D.; Benincasa, P. Blue:Red LED light proportion affects vegetative parameters, pigment content, and oxidative status of einkorn (Triticum monococcum L. ssp. monococcum) wheatgrass. J. Agric. Food Chem. 2020, 68, 8757-8763. [CrossRef]

23. Kasahara, M.; Swartz, T.E.; Olney, M.A.; Onodera, A.; Mochizuki, N.; Fukuzawa, H.; Asamizu, E.; Tabata, S.; Kanegae, H.; Takano, M.; et al. Photochemical properties of the flavin mononucleotidebinding domains of the phototropins from Arabidopsis, rice, and Chlamydomonas reinhardtii. Plant Physiol. 2002, 129, 762-773. [CrossRef]

24. Hogewoning, S.W.; Trouwborst, G.; Maljaars, H.; Poorter, H.; van Ieperen, W.; Harbinson, J. Blue light dose-responses of leaf photosynthesis, morphology, and chemical composition of Cucumis sativus grown under different combinations of red and blue light. J. Exp. Bot. 2010, 61, 3107-3117. [CrossRef] [PubMed] 
25. Javanmardi, J.; Emami, S. Response of tomato and pepper transplants to light spectra provided by light emitting diodes. Int. J. Veg. Sci. 2013, 19, 138-149. [CrossRef]

26. Li, Y.; Xin, G.; Wei, M.; Shi, Q.; Yang, F.; Wang, X. Carbohydrate accumulation and sucrose metabolism responses in tomato seedling leaves when subjected to different light qualities. Sci. Hortic. 2017, 225, 490-497. [CrossRef]

27. Cope, K.R.; Bugbee, B. Spectral effects of three types of white light-emitting diodes on plant growth and development: Absolute versus relative amounts of blue light. Hortscience 2013, 48, 504-509. [CrossRef]

28. Folta, K.M.; Lieg, E.J.; Durham, T.; Spalding, E.P. Primary inhibition of hypocotyl growth and phototropism depend differently on phototropin-mediated increases in cytoplasmic calcium induced by blue light. Plant Physiol. 2003, 133, 1464-1470. [CrossRef] [PubMed]

29. Dougher, T.A.; Bugbee, B. Differences in the response of wheat, soybean and lettuce to reduced blue radiation. Photochem. Photobiol. 2001, 73, 199-207. [CrossRef]

30. Tsukaya, H. Genetic evidence for polarities that regulate leaf morphogenesis. J. Plant Res. 1998, 111, 113-119. [CrossRef]

31. Wang, J.; Lu, W.; Tong, Y.; Yang, Q. Leaf morphology, photosynthetic performance, chlorophyll fluorescence, stomatal development of lettuce (Lactuca sativa L.) exposed to different ratios of red light to blue light. Front. Plant Sci. 2016, 7. [CrossRef] [PubMed]

32. Groenbaek, M.; Tybirk, E.; Kristensen, H.L. Glucosinolate and carotenoid content of white- and yellow-flowering rapeseed grown for human consumption as sprouts and seedlings under light emitting diodes. Eur. Food Res. Technol. 2018, 244, 1121-1131. [CrossRef]

33. Ahmadi, T.; Shabani, L.; Sabzalian, M.R. Improvement in drought tolerance of lemon balm, Melissa officinalis L. under the pre-treatment of LED lighting. Plant Physiol. Biochem. 2019, 139, 548-557. [CrossRef] [PubMed]

34. Katz, J.J.; Norris, J.R., Jr. Chlorophyll and light energy transduction in photosynthesis. Curr. Top Bioenerg. 1973, 41-75.

35. Poudel, P.R.; Kataoka, I.; Mochioka, R. Effect of red- and blue-light-emitting diodes on growth and morphogenesis of grapes. Plant Cell Tissue Organ Cult. 2008, 92, 147-153. [CrossRef]

36. Ouzounis, T.; Heuvelink, E.; Ji, H.; Schouten, H.J.; Visser, R.G.F.; Marcelis, L.F.M. Blue and red LED lighting effects on plant biomass, stomatal conductance, and metabolite content in nine tomato genotypes. Acta Hortic. 2016, 1134, 251-258. [CrossRef]

37. Rabara, R.C.; Behrman, G.; Timbol, T.; Rushton, P.J. Effect of spectral quality of monochromatic LED lights on the growth of artichoke seedlings. Front. Plant Sci. 2017, 8, 190. [CrossRef] [PubMed] 